\title{
9
}

\section{A reimagined approach to copyright enforcement from a regulator's perspective}

\author{
Kimberlee Weatherall
}

\section{Introduction}

In a copyright system designed in the public interest, what would enforcement and dispute resolution look like? Since we appear to be in the midst of a knock-down-drag-out fight over copyright enforcement which has persisted for over two decades, this qualifies as a hard question. It is inconceivable however that anyone who set out, with a blank slate, to design mechanisms for copyright enforcement in the public interest would come up with anything like our present system. Copyright enforcement is plagued with inconsistency and injustice affecting both creators and (accused and proven) infringers. At least in some parts of the world, we are caught up in a deterrence death spiral that is failing to achieve basic copyright goals.

This chapter explores some ideas for breaking away from current unproductive thinking on enforcement, drawing on regulatory theory and research in psychology. At its heart lies a thought experiment: what if we created a public copyright regulator, tasked with using a fixed pool of public resources to attempt to secure widespread observance of copyright principles? How would such a regulator approach their 
task, and what tools would they need? The public copyright regulator is not a proposal but an intuition pump: ${ }^{1}$ thinking through how such a regulator might choose their priorities gives us some clues about how we might choose our own in the real world. Perhaps the insights of regulatory theory can help us break out of a cycle of deterrence failure and escalation, and move towards a positive vision where enforcement contributes to both creators' and society's goals.

Let us be clear at the outset: the ideal copyright enforcement matrix depends significantly on the rest of copyright law. Imagine if copyright were a very narrow set of rights: say, if it consisted of limited duration, proprietary rights to exclude commercial activities that substitute for a copyright owner's own exploitation, granted only following registration and after meeting substantive thresholds, where licensing is easy, there are protections for user rights built in and individual creators secure a significant share of the returns. In such a copyright system, 'enforcement' might be largely confined to actions brought against commercial operators whose actions deprive creators of a livelihood. In that alternative universe, our chief concerns in enforcement design might be to ensure broad access to systems of justice equipped and ready to ensure that copyright's highly targeted rights are fully and frequently upheld. That, of course, is not (and will likely never be) our copyright world, as the accumulated chapters in this volume amply demonstrate (and it may not even be the copyright world we want, as again these chapters suggest). This chapter therefore assumes something like our current copyright: long, broad rights covering a wide range of subject matters with potential infringers ranging from the individual at home to the commercial counterfeiter and all kinds of public and private intermediaries in between. And in that world - ours or something very like it - we could use some new ways of thinking.

1 Daniel Dennett, Intuition Pumps and Other Tools for Thinking (WW Norton \& Company, 2013). 


\section{The deterrence death spiral}

\subsection{The costly pursuit of deterrence and its problems}

Modern copyright treaties and rules often put deterrence or similar concepts at the forefront of the enforcement calculus, ${ }^{2}$ and the rhetoric of public debate frequently links deterrence to ever-more-draconian penalties. As a result, we have seen the punitive provisions of copyright laws ... on a mindless upward curve, defying both gravity and any relationship to need or purpose' ${ }^{3}$ In no sensible world would a US law professor be able to calculate his (hypothetical) liability for an ordinary day's activities at US\$12 million; ${ }^{4}$ nor would the theoretical 2012 maximum damages bill for an iPod full of infringing content be US $\$ 8$ billion. ${ }^{5}$ And draconian punishments are not wholly hypothetical. US decisions have rendered certain unfortunates into scapegoats to appease the angry gods of general deterrence, ${ }^{6}$ awarding civil damages which dwarf any conceivable measure of harm or potential criminal fine. ${ }^{7}$ A UK student spent two years fighting extradition to the US and a threatened 10-year jail term over a website he created as a teen. ${ }^{8}$

2 Many treaties require contracting states to provide 'remedies which constitute a deterrent to further infringements': see e.g. Marrakesh Agreement Establishing the World Trade Organization, opened for signature 15 April 1994, 1867 UNTS 3 (entered into force 1 January 1995), annex 1C (Agreement on Trade-Related Aspects of Intellectual Property Rights) ('TRIPS'), Art 41.1; World Intellectual Property Organization Copyright Treaty, opened for signature 20 December 1996, 36 ILM 65 (entered into force 6 March 2002) ('WIPO Copyright Treaty') Art 14.2. Cf the European IP Enforcement Directive which uses different language, requiring that 'measures, procedures and remedies shall ... be effective, proportionate and dissuasive' (emphasis added): Directive 2004/48/EC of the European Parliament and of the Council of 29 April 2004 on the Enforcement of Intellectual Property Rights [2004] OJ L 195/16 Art 3.2.

3 William Patry, How to Fix Copyright (Oxford University Press, 2011), 194. Copyright is not the only field seeing a shift towards a more punitive style of regulation: Robert Baldwin, 'The New Punitive Regulation' (2004) 67 Modern Law Review 351, 352-360.

4 John Tehranian, 'Infringement Nation: Copyright Reform and the Law/Norm Gap' (2007) (3) Utah Law Review 537, 543-547.

5 'The $\$ 8$ Billion iPod' on TEDBlog (20 March 2012) < blog.ted.com/2012/03/20/the-numbersbehind-the-copyright-math/>.

6 General deterrence is aimed at deterring members of the general public, cf specific deterrence which is aimed at deterring the particular individual apprehended or punished.

7 High damages awards have been awarded in the US in Capitol Records Inc $v$ Thomas-Rasset $692 \mathrm{~F} 3 \mathrm{~d} 899$ ( $\left.8^{\text {th }} \mathrm{Cir}, 2012\right)$ (US\$222,000 for 24 songs made available on peer-to-peer networks); Sony BMG Music Entertainment $v$ Tenenbaum $719 \mathrm{~F} 3 \mathrm{~d} 67\left(\mathrm{I}^{\text {st }} \mathrm{Cir}, 2013\right)$ (US $\$ 675,000$ for 30 songs on peer-to-peer networks).

8 Adam Gabbat and Owen Bowcott, 'Richard O'Dwyer's two-year extradition ordeal ends in New York', The Guardian (online), 8 December 2012 <www.theguardian.com/uk/2012/dec/06/ richard-o-dwyer-avoids-us-extradition $>$. 
Today's global copyright law and order auction has spawned an unrelenting parade of new proposals to end infringement which appear at a rate which cannot be absorbed by democratic processes. From criminalisation of non-commercial activity and anti-circumvention rules, to notice-and-takedown, graduated response, website blocking and 'follow the money' approaches, advocates have moved onward and upward before the public policy processes of discussion and consensus-building for the last idea are complete. Older mechanisms are branded inadequate, but not gracefully retired. ${ }^{9}$

The public and private cost of this pursuit of deterrence is unquantified, ${ }^{10}$ but almost certainly high in some countries. In theory, society should devote resources to enforcement up to the point where the marginal benefits of fighting infringement (preferably, increased incentives and hence more creativity) equal the marginal cost of enforcement activities. No society in the world knows if it meets this benchmark. To some extent it cannot be calculated, since some of the benefits of enforcement are non-monetary: for example, the benefits from enforcement of authors' moral rights. But even leaving those issues to one side, there has been little attempt to examine the impact of enforcement initiatives on creative income. And even back-of-theenvelope calculations of the resources consumed in the quest for more perfect copyright compliance are challenging. ${ }^{11}$ Expenditure borne by the taxpayer would include: ${ }^{12}$

9 Australia in 2006 introduced a legislative scheme to allow the police to issue on-the-spot fines for infringement: Copyright Amendment Act 2006 (Cth) Schedule 1. The scheme remains on the books unimplemented. In 2010, the UK introduced a legislative framework for graduated response - that is, the application of escalating measures against internet access customers identified as infringing. Four years later, after exhaustive policy processes, no scheme is in effect and attention has shifted to industry negotiations: Digital Economy Act 2010 (UK).

10 A recent National Research Council study identified, as the first research question on enforcement, 'How much money do governments, copyright owners, and intermediaries spend on copyright enforcement?': Stephen Merrill and William Raduchel, Copyright in the Digital Era: Building Evidence for Policy (National Research Council, 2013), 3.

11 For a discussion and some efforts to this end, see Joe Karaganis, 'Rethinking Piracy' in Joe Karaganis (ed), Media Piracy in Emerging Economies (Social Science Research Council, 2011) 1, 19-20.

12 Ian Hargreaves, Digital Opportunity: A Review of Intellectual Property and Growth (UK Intellectual Property Office, 2011), 81. I note that not all of these costs are entirely borne by the taxpayer: in some cases, copyright owners will pay fees that defray or cover some of these costs. In that case, those costs become part of the private spend recognised immediately below. 
- Bureaucratic and policymaker costs: staff time within government departments and coordinating bureaucracies (e.g. the US intellectual property (IP) enforcement czar), spent on activities such as administering enforcement schemes, and analysing and consulting on proposals;

- Direct policing costs: customs, police and prosecutor time and resources (including warehousing of seized materials); ${ }^{13}$

- General civil and criminal court staff and resources, including in some countries the establishment and operational costs of specialised courts;

- Costs incurred by trade negotiators, specialised embassy staff, and seconded officials (time and travel) negotiating the expanding web of IP enforcement treaties, consulting with stakeholders, and reporting to and attending meetings of IP working groups;

- Costs of dedicated enforcement and related research programs of the OECD, WIPO, WTO, and assorted IP Offices;

- Costs of public education campaigns.

Then there is the accumulated private spending on enforcement, including:

- Investigation costs associated with civil proceedings and police processes;

- The cost of enforcement proceedings;

- Operational costs of specialist organisations like the Motion Picture Association of America (MPAA), Recording Industry Association of America (RIAA), etc.;

- Spending on lobbying and policy processes (both by right holders and by third parties responding); and

- Spending by intermediaries such as online service providers and payment service providers on notice-and-takedown, graduated response, website blocking and other enforcement activities. ${ }^{14}$

13 Or organisations such as the French online enforcement body HADOPI, with estimated costs in the tens of millions: Rebecca Giblin, 'Evaluating Graduated Response' (2014) 37(2) Columbia Journal of Law and the Arts 147, 155.

14 Industry Canada suggested that sending a single notification of alleged infringement cost large ISPs C\$11.73 (\$32.78 for small ISPs) (2006); UK government estimates were that the Digital Economy 
The total sum currently borne by society is likely to exceed that which would be considered optimal, both because it is spread across multiple parties, and owing to the disconnect between the parties receiving direct benefits (copyright owners) and parties whose resources are used to create that benefit (third parties and the public). The fact that spending is spread across a range of actors reduces our ability to consider holistically the effectiveness of the enforcement matrix. There is therefore an additional risk that, even if the overall resource allocation is excessive, there is nevertheless underspending in some areas (e.g. providing accessible mechanisms for enforcement by smaller creative operations) and overspending in others (e.g. trade negotiations that fail to provide tangible benefits). As for the disconnect, copyright owners have few incentives to be sparing in their demands on the public purse. In these circumstances the total spend is likely to exceed the resources a copyright owner would devote if they had to justify them against measurable results. We can defend expenditure of public resources by reference to the societal benefits of both copyright and public respect for law, but we should be aware of the risk of excessive spending, and apply caution when calls for new resources are made.

I return below to questions regarding how to respond to these disconnects. First, however, we need to ask: is deterrence the right framework for thinking about enforcement?

\subsection{The research on deterrence}

Research in a range of fields suggests that foregrounding deterrence and trying to achieve it through draconian penalties reflects a misunderstanding of the reasons people comply with law.

Gary Becker's classic insight is that a rational actor will adjust their behaviour in response to the expected, rather than the maximum legal sanction: that is, the legal penalty discounted to reflect the probability of being punished. ${ }^{15}$ We can increase the expected sanction either by raising the penalty, or increasing the likelihood of being prosecuted.

\footnotetext{
Act three strikes scheme would cost £290-500 million: Ian Brown and Christopher Marsden, Regulating Code: Good Governance and Better Regulation in the Information Age (MIT Press, 2013), 83.

15 Gary Becker, 'Crime and Punishment: An Economic Approach' (1968) 76 Journal of Political Economics 169; similar ideas trace back at least as early as Jeremy Bentham, The Rationale of Punishment (R. Heward, 1830).
} 
Becker's insights, however, applied to rational actors, while research in cognitive psychology underlines that human behaviour is not purely rational. Thus the empirical evidence suggests that increasing prosecution rates has greater impact; ${ }^{16}$ that perceived risk must reach a high threshold before it will have any effect, ${ }^{17}$ and that perceived risk is often lower than actual risk, making it even harder to achieve deterrence. ${ }^{18}$ It seems too that social influence has a significant impact on legal compliance: individuals' perceptions of each other's values, beliefs, and behaviour affect conduct: ${ }^{19}$ in an environment where disobedience to a legal rule seems widespread, individuals are likely to infer both that the risk of getting caught is low, and that, even if caught, they will incur little stigma or reputational cost. The combined effect is to make disobedience more likely (think about the level of compliance with road rules in Delhi).

Another challenge in relying on higher penalties to effect deterrence is that in order to be dissuaded from a course of action by law, one must have some knowledge of the law and the potential penalty, and an ability to take it into account in framing one's activities. ${ }^{20}$ It must also be possible to comply with the law without disproportionate difficulty.

Finally, in circumstances where the application of sanctions is unlikely, securing compliance with law means influencing what people do in circumstances where there is little or no threat of immediate punishment. $^{21}$ Psychologists have conducted research probing why people choose to comply with law. At least two intertwined elements

16 Dennis Nagin, Dennis, 'Deterrence: A Review of the Evidence by a Criminologist for Economists' (2013) 5 Annual Review of Economics 83; Bentham, above n 15, also identifies delay between wrong and penalty as a further factor.

17 H Laurence Ross, Deterring the Drinking Driver: Legal Policy and Social Control (Lexington Books, 1982), 105. See also Baldwin, above n 3, 373 referring to general 'risk underestimation or under-deterrence'.

18 Paul H Robinson and John M Darley, 'The Utility of Desert' (1997) 91(2) Northwestern University Law Review 453, 460-463. This is subject to an availability heuristic: people overestimate the likelihood of risks that have recently eventuated: Amos Tversky and Daniel Kahneman, 'Availability: A heuristic for judging frequency and probability' (1973) 5(2) Cognitive Psychology 207.

19 Dan Kahan, 'Social Influence, Social Meaning, and Deterrence' (1997) 83(2) Virginia Law Review 349.

20 Paul Robinson and John Darley, 'Does Criminal Law Deter? A Behavioural Science Investigation' (2004) 24(2) Oxford Journal of Legal Studies 173.

21 Tom Tyler, 'Compliance with Intellectual Property Laws: A Psychological Perspective' (1997) 29 NYU Journal of International Law and Politics 219, 224. '[A] law-abiding society is one in which people are motivated not by fears, but rather by a desire to act in socially appropriate and ethical ways ... To have a law-abiding society, we must have a polity in which social values 
impact on the likelihood of voluntary compliance with legal rules. ${ }^{22}$ First, it is easier to ensure observance of a law that is consistent with commonplace morality - that is, individuals' feelings about what is right and wrong. Second, people are more likely to comply with laws they consider legitimate: ${ }^{23}$ that is, laws that are fair and which they believe were enacted through legitimate processes. ${ }^{24}$

In sum, raising the expected sanction in order to deter infringement of the law is harder in the real world than we would expect in theory. On the other hand, compliance is influenced by other factors unrelated to deterrence: ease of compliance with the law, and whether the law is perceived to be consistent with societal or community standards, and legitimate based on the processes by which it has been made.

Consider how these insights apply to the challenge of enforcing copyright today. Technology has made infringement easy, which, if we are concerned with deterrence, suggests that we need to raise the expected sanction. Increasing the likelihood of prosecution so as to have an appreciable impact on deterrence is hard because, with very widespread infringement, even large absolute numbers of prosecutions will affect a small proportion of infringers. It will be particularly difficult for smaller creators to rely on deterrence, given their limited resources to pursue infringement: a focus on deterrence may therefore advantage certain kinds of (well-organised, large) copyright owners. The perception, fostered by copyright owners, that infringement is widespread likely lowers the perceived risk of experiencing any sanction. It may be equally difficult to raise penalties, since sanctions are already high, and radically disproportionate penalties (especially

\footnotetext{
lead them to feel responsible for following rules, irrespective of the likelihood of being caught and punished for rule breaking': Tom Tyler and John Darley, 'Building a Law-Abiding Society' (2000) 28 Hofstra Law Review 707.

22 Tyler, above $\mathrm{n} 21$. Other researchers raise additional factors but support the importance of moral consistency and legitimacy. Winter and May, for example, divide compliance influences into three categories: normative factors (Tyler's morality and legitimacy); social factors (stemming from a desire to be respected and approved, and avoid negative publicity, shame, guilt and disapproval) and calculated factors (factors such as the cost of compliance, likelihood of detection and likely penalties): Søren Winter and Peter May, 'Motivation for Compliance with Environmental Regulations' (2001) Journal of Policy Analysis and Management 675.

23 Tyler, above n 21, 224-225; 232.

24 Patry, above n 3, 186-187.
} 
when out of kilter with sanctions in other areas of law) risk being undermined by the exercise of prosecutorial or judicial discretion. ${ }^{25}$ In sum, deterrence is, at best, challenging to achieve.

The ease of complying with copyright varies significantly between countries, and between kinds of copyright content. For consumers, 'compliance' means buying legitimate copies, which may or may not be possible depending on whether and how copyright owners have chosen to make material available: as Ncube discusses in this volume, access at affordable prices is highly restricted in many countries. ${ }^{26}$ Where licensing is required, the ease of compliance depends on the ability of a prospective licensee to identify copyright owners, the willingness of copyright owners to license, and, where large numbers of works are involved, mechanisms for collective licensing. Licensing is hard, as both Gangjee's and de Beer's chapters point out, owing to copyright's long duration, fragmented ownership, and the absence of registration. This constrains or delays the creation of legitimate content distribution services, and so has feedback effects on ease of compliance for consumers.

And copyright has an image problem. ${ }^{27}$ Although the broad idea that people deserve rewards from their own creative efforts may be consistent with many people's views of right and wrong, the complex, technical rules of copyright law accreted through decades of industry-to-industry negotiations and lobbying only poorly reflect that principle. Nor is copyright widely perceived as a law that rewards creators, as contributions to this volume emphasise: in the current caricature, flesh and blood creators mostly scrape together a living (at best) while intermediaries (record companies, movie studios, technology companies) reap the profits. In less developed countries, copyright is likely seen as a law that benefits the richer developed world at the expense of everyone else. ${ }^{28}$ And even aside from a general decline in trust for government, ${ }^{29}$ at least in those countries where

25 Mark Lemley and R Anthony Reese, 'Reducing Digital Copyright Infringement Without Restricting Innovation' (2004) 56 Stanford Law Review 1345, 1405; Paul Robinson and John Darley, 'The Role of Deterrence in the Formulation of Criminal Law Rules: At Its Worst When Doing Its Best' (2003) 91 Georgetown Law Review 949.

26 For stark figures illustrating that this is often not done, see Karaganis, above $\mathrm{n} 11$.

27 Jane Ginsburg, 'How Copyright Got a Bad Name for Itself' (2002) 26(1) Columbia Journal of Law and the Arts 61.

28 Karaganis, above n 11 .

29 Tyler, above n 21. 
changes to the law have come about through trade agreements, copyright suffers from the perception that it is designed, domestically and at an international level, by big corporations against the interests of the broader population. ${ }^{30}$ This has been recognised by WIPO Chief Francis Gurry, who has argued that: ${ }^{31}$

[what] we have to do is challenge society to share responsibility for a fundamental question of cultural policy: How are you going to finance cultural production in the digital environment and in the twenty-first century? Because it can't be free. How are we going to do that? That is the question that we should ask society as a whole to share, and for which to share the responsibility.

Current copyright law does not clearly map to this goal. So an important element of a truly persuasive case is some redesign of copyright law in the public interest, ${ }^{32}$ including some redesign to try to ensure more protection for actual creators (rather than just intermediaries). ${ }^{33}$ If we are going to persuade people to observe copyright restrictions and respect the rights of creators, it does need to be a law that people can believe in, or at least accept as a necessary tool to pursue a worthy and important social end.

But for now, a single-minded focus on deterrence is a pathway to a policy death spiral. ${ }^{34}$ Most enforcement innovations are likely to fail, because infringement is easy, deterrence is not achieved, and other psychological motivators for compliance are absent. This leads to lobbying for even more draconian responses. The impetus for political action is built by creating a perception of widespread disregard of copyright which, perversely, may encourage non-compliance by normalising infringing behaviour. Higher penalties have negative feedback effects: both the spectacle of lobbying and the resulting ever-more-outrageously draconian copyright law will be presented by opponents as proof of copyright's lack of justice and legitimacy.

\footnotetext{
30 Ginsburg, above $\mathrm{n} 27$.

31 Francis Gurry, 'Copyright in the Digital Environment: Restoring the Balance: 24th Annual Horace S Manges Lecture, April 6, 2011' (2012) 35(1) Columbia Journal of Law and the Arts 1, 7. 32 In the real world - the world outside this workshop and outside this book - we can head some way in this direction with some recognition of user and public interests: for example, the adoption of fair use defences; the removal of some of the most ridiculous rules.

33 For a discussion, see Senftleben and Geiger in this volume.

34 Not every country has gone down this route, but some appear to be caught in such a cycle: the US, Australia and the UK arguably among them.
} 
The dynamics of this deterrence death spiral can be ruinous for infringers and intermediaries caught up in it. But they are also a problem for creators and creative industries. ${ }^{35}$ Imagine yourself in the shoes of the beleaguered right holder. Current systems provide limited justice; enforcement feels like a very long and losing battle against the Hydra, where no sooner is one infringer banished to oblivion but several more rise in its place. You confront an unattractive set of expensive enforcement options that incur negative publicity. Actions against uncontroversially bad actors building businesses through unconstrained infringement lead to limited, temporary successes. A copyright owner who pursues ordinary people engages in a war against fans; one who pursues intermediaries looks like an anti-technology and anti-innovation dinosaur.

We need refreshed thinking in this space based on a broader set of principles beyond deterrence. What this might mean I examine further below. But first, I should address one vision of IP enforcement: perfect enforcement through technology.

\subsection{A perfect technology of copyright justice?}

One abiding question is whether, in some future technological world, we could short-circuit even the need to persuade people to respect copyright, by moving towards frictionless copyright management. This is the vision conjured up memorably in the concept of the 'Celestial Jukebox' popularised by Paul Goldstein in the mid-1990s. ${ }^{36}$ Goldstein imagined:

a technology-packed satellite orbiting thousands of miles above earth, awaiting a subscriber's order - like a nickel in the old jukebox, and the punch of a button - to connect him to a vast storehouse of entertainment and information through a home or office receiver combining the powers of a television, radio, CD and DVD player, telephone, fax, and personal computer. ${ }^{37}$

\footnotetext{
35 This paper is not concerned with explaining why copyright interests continue to push an enforcement agenda that seems so self-destructive: see Karaganis, above n 11; Peter Drahos, 'Securing the future of intellectual property: intellectual property owners and their nodally coordinated enforcement pyramid' (2004) 36(1) Case Western Reserve Journal of International Law 53.

36 Paul Goldstein, Copyright's highway: From Gutenberg to the celestial jukebox (Hill and Wang, 1994).

37 Ibid 187. See also Janelle Brown, The Jukebox Manifesto, Salon, (14 November 2000) <www. salon.com/2000/11/13/jukebox/>.
} 
Although the technology of Goldstein's vision has dated, the shift towards streamed content and subscription services in some parts of the world potentially exceeds even the promises of Goldstein's vision. Goldstein posited that the Celestial Jukebox would not only provide access to a cornucopia of content, but would enable creators to understand their markets. Every transaction would reveal consumer preferences, and creators could channel investments ever more precisely to meet demand. ${ }^{38}$ Present day systems like Pandora, Spotify or Netflix not only fulfil these visions, but use revealed preferences as input for tailored individual recommendations - informing consumers as well as copyright owners. ${ }^{39}$ And while Goldstein's vision focused on consumer access, there are also agonisingly slow steps towards 'one click' or one-stop-shop licensing at the 'wholesale' level of copyright, embodied in technologies like Google's ContentID, which identifies use of copyright content on YouTube and offers removal or licensing options, or the United Kingdom's Copyright Hub, intended to simplify low-value licensing. In a world of frictionless copyright transactions, the role for enforcement is, in theory, much reduced, especially if the Jukebox is supported by technology that limits access to those with the right credentials.

Nevertheless, technology remains something of a wildcard for copyright and our societal goals. The perfect technology of justice remains elusive: ${ }^{40}$ the 'answer to the machine' has not yet been found in the machine ${ }^{41}$ Comprehensive digital rights management through trusted computing, an obsession of the 1990s and the other side of the Jukebox 'coin', has been eschewed by many: not least because it would require a level of centralised control over other people's devices that is Orwellian, anti-innovation, and technically challenging. The emphasis today seems to be towards technology as a means, not

38 Goldstein, above n 36, 188. Another set of approaches built on 'frictionless' copyright are arguably proposals around the greater use of copyright levies: for example, levies on internet access to compensate copyright owners for filesharing, or levies on blank media to compensate for private copying. See, for example, William Fisher, Promises to Keep (Stanford University Press, 2004).

39 Joshua Gans, Are music artists exiting the music business?, Digitopoly (31 May 2014) <www. digitopoly.org/2014/05/31/are-music-artists-exiting-the-music-business/> .

40 Lawrence Lessig, 'The Zones of Cyberspace' (1996) 48(5) Stanford Law Review 1403 ('Law as code is a start to the perfect technology of justice').

41 Charles Clark, 'The Answer to the Machine is in the Machine' in P Bernt Hugenholtz (ed), The Future of Copyright in a Digital Environment (Kluwer Law International, 1996), 139. 
for control of content in the hands of consumers, so much as for either blocking access (for example, through website or geo-blocking) or to detect infringers through sharper online surveillance.

There are serious questions too whether a frictionless copyright world is a desirable societal goal from a creator's perspective. First, it is not obvious that such a vision works beyond content like music. Music may lend itself to the all-you-can-eat model (although some musical artists and fans would disagree), but what about books? Or visual art? And if investment is perfectly informed by data analysis would the result be infinite diversity, or the triumph of the bland? There are also questions about who benefits: ${ }^{42}$ artists have raised concerns about returns from subscription services like Spotify. ${ }^{43}$ If the Celestial Jukebox is a vertically integrated monopoly or oligopoly, would independent creators be excluded, or what would they have to give up in order to be included?

There are also problems from a user perspective. The model would likely involve perfect price discrimination: that is, charging consumers different prices for the same content, where the price variation cannot be explained by variations in costs. Perfect price discrimination is controversial: it involves significant wealth transfer from consumers to creators/distributors but also perhaps facilitates access for the disadvantaged. ${ }^{44}$ And finally, in a perfectly controlled world, questions arise about how we ensure activities presently enabled by copyright exceptions. ${ }^{45}$

In sum, at least for now, technology is either not an answer, or not the answer that we want, although technology can of course provide partial answers to specific issues and is doing so successfully.

\footnotetext{
42 See generally Greg Lastowka, 'Walled Gardens and the Stationers' Company 2.0' (Working Paper, 21 January 2013), available at <ssrn.com/abstract=2204465>.

43 Rebecca Giblin, 'Reimagining copyright's duration', Chapter 6 in this volume.

44 Fisher, above n 38, 164-169.

45 See generally Dan Burk and Julie Cohen, 'Fair Use Infrastructure for Rights Management Systems' (2001) 15 Harvard Journal of Law and Technology 41.
} 


\section{A thought experiment: Introducing the public copyright regulator}

This volume is built on the idea that a thought experiment can help us to see beyond current problems. And so to break out of the deterrence death spiral and deal with enforcement holistically, I imagine how a hypothetical public regulator of copyright might approach their task, drawing some inspiration from Ho's Representative Individual discussed in Chapter 1.

Imagine you are appointed as the first public copyright regulator, tasked with promoting widespread observance of copyright norms. You will be provided with a fixed level of resources (ample, but not infinite). Your task will be to survey the infringement landscape and tools available to address it, prioritise enforcement activities, and devise mechanisms for addressing infringement effectively and efficiently. You will have overall responsibility for copyright enforcement across the board. You will also design the regulatory tools, the powers and remedies you will need, and policies to guide use of those tools. What powers would you consider essential, and what principles would guide your decision-making? What goals would you adopt, and how would you prioritise in allocating your resources?

Adopting the perspective of the hypothetical public copyright regulator is a tool for reimagining copyright enforcement in the public interest. Such a regulator should focus on the societal rather than the private interest in copyright and in enforcement of rights. Her primary aim should be to maximise the societal benefits of copyright: that is, to promote the interests of all individuals in society in the aggregate, creators, consumers and others. ${ }^{46}$ My assumption is that the chief goals of copyright are to provide incentives for the production and dissemination of a diverse range of creative works, in order to ensure (1) fair returns for creators, enabling at least some creators to make a living from their work; (2) access to creative and informational works for the broader society; and (3) broad opportunities for participation in the cultural life of the community, enjoyment of the arts and sharing

46 For a discussion of the concept of the public interest, including the 'aggregate' approach, see Chapter 1 in this volume. 
in scientific advancement and its benefits. ${ }^{47} \mathrm{~A}$ focus on diversity and on enabling creators to make a living implies a concern particularly with individual creators.

An obvious objection to my thought experiment is that copyright is not susceptible to public management and enforcement. Copyright, a critic might say, creates proprietary interests, and it is the task of copyright owners to enforce their property rights, if necessary by suing infringers in the civil courts for copyright infringement. But this is a caricature of copyright as it really exists in most countries.

In common with a wide range of property rights, we already treat respect for copyright as a matter of public interest by creating criminal sanctions for breach. Further, copyright today has many regulatory aspects: ${ }^{48}$ various countries have piecemeal public systems for mediating certain disputes and making adjustments to IP rights for assorted public purposes. ${ }^{49}$ Administrative tribunals exercise oversight over copyright licensing ${ }^{50}$ and create exceptions, ${ }^{51}$ public officials make numerous enforcement decisions. ${ }^{52}$ Further, current enforcement initiatives focus on making parties other than the copyright owner (including non-infringing parties) spend resources on enforcement: this can only be justified by a belief that there is some public interest in the enforcement of copyright beyond the pure private interest of right holders: otherwise, we would expect that right holders would

47 To adopt the language of article 27 of the Universal Declaration of Human Rights.

48 Joe Liu, 'Regulatory Copyright' (2004) 83(1) North Carolina Law Review 87; Kimberlee Weatherall, 'Of copyright bureaucracies and incoherence: Stepping back from Australia's recent copyright reforms' (2007) 31(3) Melbourne University Law Review 967; Thomas Streeter, 'Broadcast Copyright and the Bureaucratization of Property' (1992) 10 Cardozo Arts and Entertainment Law Journal 567; Shuba Ghosh, 'When Property is Something Else: Understanding Intellectual Property through the Lens of Regulatory Justice' in Axel Gosseries, Alain Strowel and Alain Marciano (eds), Intellectual Property and Theories of Justice (Palgrave Macmillan, 2008).

49 Examples include Ofcom's role in the (stalled) three strikes system established by the Digital Economy Act 2010 (UK); the public bureaucracy established to administer a 'three strikes' system for penalising infringing users in France; the US Register of Copyrights process for creating new exceptions to anti-circumvention law; Australia and New Zealand's Copyright Tribunals; competition authority oversight of collecting societies in Australia and the US: for an overview of some of the Australian processes see generally Weatherall, above $\mathrm{n} 48$; in the US see Liu, above $\mathrm{n} 48$. 50 Australian Copyright Tribunal; UK Copyright Tribunal; New Zealand Copyright Tribunal; Copyright Board of Canada.

51 For example, the role assigned to the US Register of Copyrights in creating exceptions to the prohibition on circumvention of copyright technological protection measures under 17 USC $§ 1201$.

52 Both customs officers and police officers must make decisions whether to pursue enforcement when informed of infringement by copyright owners. 
have to pay intermediaries to get involved. In short, no natural pattern for the mix of private and public involvement in enforcement would be violated in establishing a copyright regulator. ${ }^{53}$

In early drafts of this chapter I contemplated imagining enforcement of copyright, for the purposes of this experiment, as an exclusively public function, depriving authors and intermediaries of standing to bring proceedings. There were three difficulties with imagining copyright as a purely public right. First, as Gangjee has pointed out in his chapter, the more abstract our thought experiment, the less we can learn from it when we 'return' to thinking about copyright as it is today. Second, it would be unprecedented to treat a proprietary right thus, and even beyond property there are relatively few legal rules we treat as exclusively matters for public vindication: murder and manslaughter can be the subject of civil proceedings for wrongful death. Third, such an approach would remove from the thought experiment the interesting and difficult questions we face around how to manage the interface between public and private enforcement initiatives.

Instead, therefore, I have chosen to imagine a public copyright regulator who has the usual tools of the state to enforce the law. These include police powers: the power to initiate both criminal proceedings with a view to criminal convictions, fines and possibly imprisonment; powers via customs procedures to prevent entry of infringing goods into the jurisdiction. They also include powers to commence civil proceedings for infringement seeking civil remedies including injunctions and damages (with a view to obtaining rulings on important issues, or on behalf of copyright owners who suffer harm); powers to require alternative dispute resolution or seek enforceable undertakings from private parties in lieu of court proceedings; and the power to provide authoritative information around copyright and undertake public

53 The mix of private and public enforcement can vary significantly, both across areas of law, and within areas of law but across jurisdictions. Cf the extended literature in the field of corporate law illustrating the different mixes of private and public enforcement in corporate law: e.g. Howell E Jackson and Stavros Giantinis, 'Markets as Regulators: A Survey' (2007) 80 Southern California Law Review 1239; John C Coffee Jr, 'The Law and the Market: The Impact of Enforcement' (2007) 156 University of Pennsylvania Law Review 229, 256; Eloise Scotford and Rachael Walsh, 'The Symbiosis of Property and English Environmental Law - Property Rights in a Public Law Context' (2013) 76(6) Modern Law Review 1010. 
education campaigns. Comparable regulators would include the US Federal Trade Commission, the UK's Ofcom, or Australia's Australian Competition and Consumer Commission (ACCC).

In my thought experiment, copyright owners would still be entitled to bring actions for copyright infringement seeking to recover damages. The public regulator would have the power to intervene in such private litigation, for the limited purpose of making submissions on questions of public interest which might arise and which might not otherwise be aired in an adversarial litigation system.

Obviously this is a thought experiment, or intuition pump, not a proposal. Not only does my simplified thought experiment violate principles regarding the separation of powers which are fundamental in at least some countries, but my hypothetical is clearly idealised. In the real world, a public copyright regulator would risk being captured, or focusing in a narrow and single-minded way on copyright enforcement at the cost of broader societal goals. My hypothetical regulator takes a broad view of the public interest rather than assessing her performance by reference only to enforcement- or infringementrelated Key Performance Indicators (KPIs). Few actual regulators would refuse the expansion of their powers, but mine binds herself, Odysseus-like, removing the temptation to overuse regulatory power by precommitting to limited and tailored powers. In other words, she is superhuman. Superhumans are useful in a thought experiment: trying to find one and appoint her is quite a different matter.

\section{What would the public copyright regulator do?}

The next stage of the thought experiment is to consider when and how the public copyright regulator would use her powers. The discussion necessarily proceeds at a high level of generality, but even so, significant differences may be observed between thinking this way, and how enforcement works currently. 


\subsection{Principles guiding when the regulator uses her powers: Copyright's quid pro quo}

If society's goals for copyright are, as discussed above and in Chapter 1 , both to promote creativity and to ensure access and participation, this implies a quid pro quo: creators are granted rights in return for societal benefits, and the public copyright regulator is entitled to enforce both sides of the bargain.

This means that the enforcement orientation of a public copyright regulator differs from that of the private copyright owner. An emphasis on copyright's quid pro quo suggests not only that compulsory licences will sometimes be appropriate, but also that, both in considering the allocation of resources towards enforcement, and what remedies to seek, ${ }^{54}$ she could justifiably take into account the absence or degree of public access to the relevant content. The regulator ought to (with some qualifications considered below) prioritise spending of enforcement resources on material made readily available to the public (whether in the private market, or through reasonably priced access in public institutions like libraries), and refuse to spend public resources where materials are not available, or negotiate for better access as a precondition of devoting public resources to enforcement. Note that this approach has a beneficial feedback effect: to the extent that infringement is exacerbated by a lack of (reasonably priced) legal alternatives, then a regulator who improves access simultaneously helps reduce infringement.

This reasoning would need to be qualified in situations where copyright content is in draft form and/or will be available imminently: subject to comments below regarding delayed release windows, a creator planning to exploit their material ought, in general, to be the first one to release material publicly and gain the benefits of a welltimed, well-promoted first release. Distinct considerations might apply to certain kinds of content, such as the products of indigenous peoples' creativity which may be governed by very different rules. Questions might also arise regarding moral rights: a creator's right to

54 I am clearly not the first person to think of this: see e.g. Pamela Samuelson, 'The Copyright Principles Project: Directions for Reform' (2010) 25 Berkeley Technology Law Journal 1175, 12231226 (suggesting availability should be relevant to court decisions to grant or refuse injunctions). 
be recognised and to exercise some control over the presentation of their work may also require a different approach: a point to which I return below.

My argument that enforcement and remedies can legitimately be conditioned on access might be criticised for re-writing copyright law as a 'use it or lose it' system inconsistent with its history and with the recognition of authors' natural rights. Within the bounds at least of this thought experiment, I do not resile from that position: perhaps copyright should be 'use it or lose it', subject to the exceptions mentioned above. Regardless of how it might be used in the real world, copyright is neither designed nor intended to provide a default privacy law or a mechanism for private censorship..$^{55}$ In any event, we are talking about the expenditure of public enforcement resources: nothing in this analysis would prevent a copyright owner from bearing the full costs of enforcing their own copyright. ${ }^{56}$ Demanding some level of access in return for enforcement of copyright is not a demand that copyright owners subsidise the public, rather, it is a refusal to subsidise creators in the absence of clear societal benefit.

Harder questions arise if copyright content is available, but on unreasonable terms: for example, it is unaffordable to 90 per cent of the population. ${ }^{57}$ I would propose however that a public copyright regulator spending public resources is entitled to take into account broader issues of equity and distributive justice, and treat such material as functionally unavailable. This could be justified as a matter of basic democratic principles external to copyright. It could also be justified by reasoning internal to copyright: if we want to encourage creativity in the long term, then ensuring broad access to culture is more likely to encourage participation in creation from the broadest

55 Some people use copyright to enforce privacy or commercial confidentiality in unpublished material. The focus here, however, is on copyright in the public interest: privacy interests ought to be managed by the law of privacy or commercial confidentiality; they cannot be appropriately addressed through copyright. Reliance on copyright leads to anomalies. For example, copyright can protect privacy in emails or in unpublished letters, but does not confer property rights on the subject of an (intimate) photograph or film.

56 Subject to cases where a compulsory licence would be appropriate: i.e. in circumstances where the public interest in use of copyright material overrides the copyright owners' rights to allow use, and where payment is appropriate. Different countries have different rules governing when compulsory licences are available, and the limiting principle at an international level would be the three-step test.

57 Karaganis, above $\mathrm{n} 11$. 
possible proportion of the population. Remember that creators themselves are not always from the wealthiest parts of the community, and themselves require access to a full cultural storehouse to feed their own creativity.

Further, and bearing in mind the discussion earlier, remember that the regulator must take into account (a) the need for regulatory tools of persuasion as well as coercion and (b) evidence emphasising the importance of the law being seen as both consistent with morality and legitimate. Building a persuasive case for copyright is going to be much more difficult where it serves only the wealthy elite. The issues obviously become more difficult where the disparity in access is less stark: what if material is available to 50 per cent of the population? At what point is it the responsibility of the State to step in to subsidise access? Nevertheless, the principle is clear: equitable access is a valid consideration for a public copyright regulator in determining the distribution of enforcement resources.

What if material is going to be made available, but at a later date than elsewhere? Do copyright's goals require timely public access to content? There is no single principled answer to this question. On the one hand, to the extent that we are concerned about copyright incentives, there are arguments in favour of release 'windows' chosen by copyright owners to maximise their returns. On the other hand, a public copyright regulator could legitimately question whether they should devote their limited resources to sheltering copyright owners from the impact of disruptive technological innovation and globalisation, when at least part of the solution lies in their own hands via global release dates. ${ }^{58}$ The regulator's response would likely depend on the nature of the material. She might offer incentives for earlier release (for example, providing targeted enforcement around the release date). But in cases where copyright content is an input to other businesses - for example, if local businesses were denied or charged highly disadvantageous prices for software necessary for international competitiveness - then the position becomes much starker, and there might be a public interest case for refusing to lift a finger.

58 Patry, above $\mathrm{n} \mathrm{3,} \mathrm{186.} \mathrm{To} \mathrm{the} \mathrm{extent} \mathrm{that} \mathrm{delays} \mathrm{in} \mathrm{release} \mathrm{are} \mathrm{due} \mathrm{to} \mathrm{State} \mathrm{action}$ (e.g. censorship processes) this reasoning would not apply. 
Another objection will doubtless have occurred to the reader by this point. I seem to be proposing that a public copyright regulator sit in judgment over copyright owners' decisions regarding timing, pricing, and means of distribution. Surely the market best decides how to distribute the rewards of creativity, and by creating proprietary rights in content, copyright allows consumers, through the market, rather than patrons, or the State, to determine which creators succeed, and their level of reward? As de Beer points out, our assumption has been that some matters are best dealt with by rules outside copyright.

I acknowledge that emphasising copyright's quid pro quo reduces copyright owners' control; the assumption in this chapter is that we grant rights of control for societal benefit, not the natural rights of the creator. But again, there are a number of responses. First, I am assuming that a copyright owner could still delay or limit access to their content and/or charge very high prices, provided they are prepared to bear the full costs and risks of this strategy. Second, the expenditure of public resources on enforcement can be characterised as a subsidy to copyright owners that supports pricing and distribution strategies that would not otherwise be possible: we are not in fact operating in a 'pure' market in any event. Third, I am not arguing that the regulator should sit in judgment on content: if we accept that a goal of copyright is the production of diverse content, then there should be no expectation that enforcement investment of a regulator would depend on content being 'worthy'.

\subsection{What remedies would a public copyright seek, and when?}

Having established the kinds of cases in which a public copyright regulator would exercise their powers, the next question is, what remedies or enforcement approaches would they use? In thinking through this issue from a regulator's perspective, we can benefit from considering regulatory theory.

Regulatory theory explores ways to direct limited resources to further the substantive goals of the law and promote widespread compliance. This literature suggests that a regulator ought not always meet infringement with legal action (civil or criminal). While having the ability to escalate enforcement action to serious penalties is a tool regulators can use, such penalties should not be a regular occurrence. 
Unlike much of our debate in copyright, regulatory theory does not foreground a simple model of deterrence linked to draconian penalties, but builds in a role for the tools of persuasion.

According to responsive regulation theories, regulators' tools for securing compliance can be conceptualised as a pyramid. At the wide base are the soft tools of persuasion: guidelines, educational strategies, and engagement of regulated parties in a dialogue. The presumption is that the regulator should start with these tools, which are less costly and coercive and can therefore be more broadly employed, and can, where an actor is inclined to be law-abiding, secure voluntary compliance. When such methods fail, then the regulator should deploy progressively more coercive tools: industry co-regulatory schemes; civil proceedings seeking court orders for damages and/ or injunctions. Irrational actors who cannot be persuaded any other way may need to be 'incapacitated' (i.e. prevented from doing harm), whether that means imprisonment, loss of a licence or closure of a business. Generally, the regulator adopts a 'tit for tat' approach which assumes people wish to act virtuously until events prove otherwise. ${ }^{59}$ Persuasion and deterrence are linked in an overall strategic approach in which the regulator is a 'benign big gun', one who 'speaks softly but carries a big stick'. This variegated stance stands in marked contrast to a mentality which assumes all infringers are bad people who are deterred only by threat of punishment.

The later regulatory literature elaborating on this basic model recognises that enforcement in the real world is complex. It can be wasteful, for example, to always start at the base of the enforcement pyramid. In some circumstances it may be more efficient to target certain kinds of actors: commercial counterfeiters do not deserve a 'softly softly' approach. In addition, 'smart regulation' proponents note the potential for moving 'across' regulatory techniques rather than just 'up' the pyramid. For example, ex ante controls (like screening) or non-state controls (norms, markets) may be more effective. ${ }^{60}$ It may be possible

59 To a copyright reader, this may sound like graduated response, but don't be too sure: as discussed below, current graduated response schemes are more like a caricature rather than a faithful embodiment of responsive regulation approaches.

60 Neil Gunningham and Peter Grabosky, Smart Regulation (Clarendon Press, 1998), Chapter 6; see also Richard Johnstone, 'Putting the Regulated Back into Regulation' (1999) 26 Journal of Law and Society 378, 383. 
to change the environment, or 'architecture', ${ }^{61}$ to make compliance easier and non-compliance harder. This takes us back to the question of technology: in the copyright field, it could involve attempts to make infringement physically difficult or impossible, through digital rights management or other intermediary-based techniques, such as website blocking or notice-and-takedown. As discussed above, these kinds of techniques raise issues around accountability, transparency, and the potential impact on innovation; nevertheless, they illustrate that escalation is not the only approach.

Another qualification is that big sticks are not always good, and bigger sticks are not always better. Consistent with the earlier discussion, moral intuitions and the legitimacy of regulation matter. This means that fairness and proportionality, and not just whether an infringer is compliant or recalcitrant, are important when assessing penalties: the rule of law is discredited if large actors who cause serious societal harm (but comply when caught) are punished significantly less than individuals who cause little harm. ${ }^{62}$

Further, empirical research suggests that attempting to characterise illegal behaviour as immoral where this view is not widely shared can backfire, leading to resistance rather than compliance. In one case study by Christine Parker, an Australian regulator sought to require firms accused of cartel behaviour to acknowledge their wrongdoing, and publicised the criminal nature of the behaviour. Regulated firms responded by lobbying for restraints on the regulator. ${ }^{63}$ We have seen similar dynamics emerge when right holders have attempted to paint downloading copyright material as a criminal act akin to stealing a handbag: such attempts have led to parody rather than a change in culture.

One objection to using regulatory theory in the context of copyright enforcement is that theories like responsive regulation were developed in the context of industry regulation and assume a relationship between regulator and regulated of some longevity, involving repeat interactions, in which the regulator can try different approaches and in which the regulated parties get to know the regulator's attitudes

61 Lawrence Lessig, Code and other laws of cyberspace (Basic Books, 2000).

62 Karen Yeung, Securing compliance: A principled approach (Hart Publishing, 2004) 168-170.

63 Christine Parker, "The "Compliance" Trap: The Moral Message in Responsive Regulatory Enforcement' (2006) 40(3) Law \& Society Review 591. 
and approaches. There is some truth to this objection, but I do not think it fatal. First, there are many contexts for copyright 'dealings' which do fit the classic regulation model: think, for example, about large users of copyright material (educational institutions, media organisations, internet intermediaries) and large copyright rights organisations. Second, it is by no means clear that regulators in general do have ongoing relationships with the objects of regulation (Australia's corporate regulator would have little contact with the vast majority of registered companies in Australia).

Certainly the copyright enforcement environment is complex, with many different kinds of infringement, ranging from the market counterfeiter (and their online equivalent), through to legitimate businesses and institutions through to a range of different individuals. The creator and copyright owner landscape is also complex, ranging from individual and small creatives (who may be operating in niche or popular contexts) through to larger creators and intermediaries engaged in production/publication and distribution.

Despite this complexity, the literature on regulatory theory provides useful insights when it comes to how remedies might work better in copyright. It is not at all clear that copyright as currently written benefits from these various insights. While regulatory theory recommends a strategic and varied approach, in which different cases are treated differently, and the most serious penalties are reserved for the most serious and recalcitrant offenders, current copyright infringement and remedial rules are drawn broadly and treat unlike cases alike. ${ }^{64}$ Good faith or attitude on the part of the infringer is mostly disregarded in analysing infringement. ${ }^{65}$ Penalties and remedies in copyright present, not as a pyramid, but a great, fat cone, with no clear apex. Our hypothetical public copyright regulator should undertake some sharpening.

64 For example, criminal copyright laws in developed countries treat single and isolated infringements in a commercial context as criminal, regardless of the impact on copyright owners' interests. US copyright law subjects non-commercial infringement to the same punitive statutory damages awards as would be available against a commercial counterfeiter.

65 Many jurisdictions do recognise defences for 'innocent infringers'. Such defences, however, are often limited to actors who neither knew, nor had the opportunity to know that their conduct involved infringement. Thus a good faith actor who was merely ignorant is not necessarily excused. Innocent infringer defences also tend to limit monetary, but not other remedies. 
There is no lack of ideas for constructing a fiercely pointy enforcement apex for the most harmful and recalcitrant infringers. In many countries, serious, commercial, deliberate infringement of copyright attracts criminal penalties, ${ }^{66}$ including imprisonment. ${ }^{67}$ These ought to be 'apex' punishments, rarely applied: criminal liability has a special impact, imposing stigma that can lead to long-term limitations on the life choices of a person, or the prospects of a business. ${ }^{68}$

Internationally, however, there has been a push, particularly by the US, to treat single commercial infringements of copyright as criminal acts. ${ }^{69}$ Such laws are sometimes justified on the basis that they are necessary to ensure proceedings do not fail on technical issues of proof. On this view, while the law may be drafted broadly, a prosecutor or regulator can apply the law in 'pyramid fashion'. There are problems with this argument, however. The availability of serious penalties for ordinary commonplace behaviour not harmful to copyright owners creates inconveniences for legitimate businesses, and brings the law into disrepute. Opponents love to satirise the absurdity of extreme copyright. Second, to the extent that the provision of serious penalties serves the rhetorical purpose of conveying the seriousness of infringement, that message given is muddied by over-extensive provisions. A public copyright regulator who takes seriously the research around regulation and compliance with law will take different approaches for different kinds of infringers, and will want to ensure that their enforcement system has 'teeth', without breeding disrespect for the law through an excessively punitive approach. Assuming they do, as suggested, wish to precommit to limited use of remedies,

66 Required by TRIPS, Art 61.

67 Required by ACTA (Anti-Counterfeiting Trade Agreement, opened for signature 1 May 2011 [2011] ATNIF 22 (not yet in force)) but not by TRIPS; examples include UK (Copyright, Designs and Patents Act 1988 (UK), s 107), Australia (Copyright Act 1968 (Cth) ss 132AC-132AM), and US (17 United States Code $\S 506(a)$ and 18 United States Code $\S 2319(\mathrm{~b})$ ).

68 Douglas Husak, Overcriminalisation: The Limits of the Criminal Law (Oxford University Press, 2008).

69 The argument that single or small-scale commercial infringements ought to be treated as criminal was central to the US' dispute with China in the WTO: Panel Report, China-Measures Affecting the Protection and Enforcement of Intellectual Property Rights-Report of the Panel, WTO Doc WT/DS362/R (26 January 2009). The US has also pushed to include such provisions in recent trade agreements, including, most recently, Art 18.77.1 of the Trans-Pacific Partnership Agreement between the Government of Australia and the Governments of: Brunei Darussalam, Canada, Chile, Japan, Malaysia, Mexico, New Zealand, Peru, Singapore, United States of America and Vietnam ('TPP'), signed 4 February 2016 [2016] ATNIF 2 (not yet in force). 
criminal liability in particular should be available only in extreme cases: of commercial, market-substituting uses or deliberate, sustained undermining of creators' markets.

In both the legislative design and application of remedies, therefore, the public copyright regulator would 'triage' infringement complaints. There are some obvious bright lines that might be drawn: commercial $\mathrm{v}$ non-commercial; acts which cause substantial harm $\mathrm{v}$ acts which do not; substitution for the copyright owner's exploitation $\mathrm{v}$ unauthorised use in the context of non-competing activities. There surely are cases which should only ever be disputed in a civil context: infringement by public/non-commercial institutions, and arguably, infringement that does not involve market substitution for the original product.

In the regulatory theory, too, 'incapacitation' is an apex remedy: one that ought not be a commonplace occurrence. A range of incapacitating remedies are included in many copyright laws: permanent seizure and destruction of infringing articles,$^{70}$ seizure of implements used to infringe, and confiscation of proceeds of crime and assets traceable to the proceeds of crime. ${ }^{71}$ Again, regulatory theory would suggest that remedies of these kinds ought to be sparingly used and explicitly confined to serious cases. It is also possible that such remedies, which go beyond compensation for harm and stray into the realm of punishment, ought to be either confined to proceedings brought by the regulator or only sought in private proceedings with the leave of the regulator.

\subsection{How would the regulator allocate resources?}

Another key set of questions for the public copyright regulator is how they would allocate their resources across the range of enforcement activities. An idealised public copyright regulator would have a budget, and would undertake both a prospective cost/benefit analysis of enforcement initiatives and ex post review to assess the value for money of past initiatives.

70 TRIPS, Art 61; ACTA, Art 25.

71 ACTA, Art 25. 
She faces some interesting conundrums. She could consider, for example, which provides better value: customs or police? If she can cover, say, a fixed number of full-time equivalent salaries for officers to act on copyright enforcement, what proportion of her human resources should be devoted to stopping pirated goods at the border, and what proportion to police addressing a broader range of copyright crime? What proportion devoted to enforcement online, and how much to physical infringement? Is it possible to make an informed assessment regarding the relative harm caused by the different forms of infringement? Or, assuming she has set a budget to address widespread online infringement of popular content, how could those resources best be allocated: to blocking gateway websites? To identifying infringing consumers and taking steps to educate them? To more general education campaigns?

While I would not argue that these various mechanisms for securing compliance with copyright are substitutable, I would suggest that they should be considered together and that a public copyright regulator would want to assess their relative effectiveness and allocate resources accordingly. One of the most valuable things a regulator could do would be to perform a dispassionate analysis of the relative benefits of different enforcement mechanisms: perhaps seeking input from a broad range of copyright owners and creators as to their enforcement priorities to inform that analysis.

The very existence of a regulatory pyramid suggests that some proportion of resources ought to be devoted the soft tools of persuasion as an integral part of an overall enforcement strategy: seeking to encourage compliance both by making it easier, and by increasing awareness and understanding of the law. Governments, such as the Australian government, have often discussed the need for copyright owners to address access questions to encourage compliance, without seeing the promotion of that access as part of their role. Seeing these questions through the lens of regulatory theory, however, suggests that in fact, promoting copyright's quid pro quo is part of the role of the State, and integral to successful enforcement.

Controversially, integrating persuasive techniques might well include attempting to target educative efforts on infringers who might be convinced to comply - for example, by having online service providers send infringement notices to BitTorrenting users. The astute 
reader will immediately see that this suggestion looks like a watered down version of graduated response. But a public copyright regulator will inevitably have limited resources - which means that not every identified infringement is going to lead to a notice. ${ }^{72}$ She will also want her notices to be effective. One way to do so is to make the message concrete, rather than abstract. A targeted form of infringement-andeducation notice might therefore be based around targeted campaigns relating to particular (legitimately available) content and around particular economically important points in time, like release dates.

Regulatory theory also recognises that regulators may need to focus resources based on an assessment of the risks that certain persons, firms, or behaviour pose to their overall objectives. ${ }^{73}$ Some forms of non-compliance are cheaper and more efficient to address than others. ${ }^{74}$ This could mean targeting behaviour that creates the most havoc for copyright owners; or focusing on actions that offer the best chance for the highest risk reductions for a given level of expenditure. Some care must be taken however in applying these latter principles, because economic efficiency, and the economic magnitude of harm, are not the only considerations relevant to copyright enforcement. Many of the chapters in this volume emphasise the need to promote the interests of individual creators. The discussion above has added its own note to this chorus: ensuring that copyright is more clearly linked to its goals, and genuinely promotes the interests of creators is likely to contribute to the overall legitimacy of copyright, and hence to the persuasive factors that will assist in encouraging compliance. Consistent with this reasoning, another goal of the public copyright regulator ought to be to ensure that some proportion of the resources devoted to enforcement benefit individual creators, perhaps by devoting some proportion of the resources allocated to bringing test cases or civil proceedings to cases brought on behalf of, or cases that are important to, such creators (for example, by clarifying legal questions important to such creators).

72 Giblin, above n 13.

73 See generally Robert Baldwin and Julia Black, 'Really Responsive Regulation' (2008) 71

Modern Law Review 59, 65-68 (describing risk-based approaches), and sources cited therein.

74 Ibid 66-67. 


\subsection{How would the work of a public regulator interact with technology and technological intermediaries?}

A final question of interest is how the public copyright regulator ought to operate in the digital environment. Technology is the scene of many of the great ongoing battles in copyright enforcement. Beyond cases where the intermediary is a wrongdoer (for example, they set out to induce infringement or build a business based on infringement), intermediary liability is sometimes justified on the basis that it offers more efficient enforcement than taking action against individual infringers. Conversely, intermediary liability is criticised for shifting enforcement costs from copyright owners to third party businesses and to their customers, some of whom are innocent. Since intermediary liability involves using the intermediary as a 'tool' to get to ultimate infringers, the question arises: is this a tool that a public copyright regulator would seek to use, and if so, how?

A public copyright regulator ought, for all the obvious reasons, to be very slow to start dictating technological design, and as a general principle, ought not to get distracted by the goal of 'solving' infringement through 'the machine'. As Brown and Marsden noted some time ago, a focus on trying to solve the issue of infringement this way has 'distracted attention from business innovation for more than a decade'.${ }^{75}$ Nevertheless, a copyright regulator who wants creators to receive benefits from their creativity cannot remain entirely agnostic about technology and the direction of its development, since clearly technology can develop in ways that are more, or less, supportive of creators' interests, and more or less supportive of other societal interests in copyright. Is there action a public regulator should take to encourage the development of technology in ways supportive of the goals of copyright?

For example, to what extent should the copyright regulator back copyright owner attempts to manage enforcement through technology, for example, by prohibiting the circulation of circumvention technology? It is clear that such technologies can play a useful role in copyright enforcement. ${ }^{76}$ From the perspective of regulatory

75 Brown and Marsden, above n 14, 86.

76 Samuelson et al, above $\mathrm{n} 54$. 
theory, such technology, by making it more difficult to infringe, may encourage observance of copyright principles - especially if coupled with moves to make compliance easier by making material accessible at a reasonable cost. On the other hand, a regulator concerned with other societal benefits of copyright - including access and, importantly, participation in cultural life and the arts - would wish to encourage development of 'smarter' measures which do not prevent legitimate activity including valuable forms of reuse. On this basis, it would be legitimate to take into account the impact of any technological measures adopted by a copyright owner on public access in determining enforcement priorities. To the extent that a copyright owner chooses to implement technological measures and fails to take account of legitimate uses, they have freely chosen technology over copyright, and could, perhaps, be held to that choice.

To what extent should digital intermediaries be required to enforce copyright, or develop internal technologies to help enforce copyright? At present, both copyright exceptions, and principles of primary and secondary liability already play a role in encouraging service providers to participate in deploying reasonable measures and discouraging widespread infringement. In the US, it is notable that the desire of technological intermediaries to make out a defence of fair use has led, in cases like HathiTrust ${ }^{77}$ and in the context of the Google Book project, ${ }^{78}$ to technological design that seeks to protect owner interests. And, as Samuelson et al note, 'safe harbors are an important legal device that can be used both to limit liability in appropriate ways and to encourage those providers to help reduce widespread infringement' ${ }^{\prime}{ }^{79}$ There is therefore attraction to Samuelson et al's proposal to provide a safe harbour for intermediaries who deploy reasonable, effective, and commercially available measures to minimise infringement.

77 Authors' Guild v HathiTrust, 755 F 3d 87 (2 ${ }^{\text {nd }}$ Cir, 2014).

78 Authors Guild Inc $v$ Google Inc, 804 F 3d 202 ( $2^{\text {nd }}$ Cir, 2015).

79 Ibid. See also Eric Goldman, 'Want to end the litigation epidemic? Create lawsuit-free zones', Forbes.com (online), 10 April 2013, <www.forbes.com/sites/ericgoldman/2013/04/10/ want-to-end-the-litigation-epidemic-create-lawsuit-free-zones $/>$. Goldman argues that safe harbours provide useful 'lawsuit-free zones,' thus avoiding 'the individual and social costs of adjudicating disputes, including the settlements payments to get rid of nuisance and otherwise meritless lawsuits. Plus, lawsuit-free zones stimulate business investments by providing more legal certainty to entrepreneurs, which should translate into more jobs. So finding ways to dial down litigation might be the best "jobs stimulus" effort our legislators could undertake.' 
How far would we take the idea that efficient enforcement through technology is something a public copyright regulator would seek to promote? Pushing the idea further might involve a regulator paying or subsidising intermediaries to act: an idea that is less outrageous than it sounds, given the extent of public funding that has been applied to promote recent enforcement initiatives. A public copyright regulator might well wish to have at least some involvement in private enforcement developments. Industry schemes for managing copyright infringement online have come to particular prominence in recent times: in 2014, the US Copyright Alert system commenced operations, sending escalating notices to customers detected engaging in online copyright infringement, based on a Memorandum of Understanding between a number of large internet access providers and copyright owners. Similar industry schemes have been considered in both the UK and Australia. ${ }^{80}$

This raises the important question of how far we ought travel down the path of 'governance' rather than 'regulation'. 'Governance' is an umbrella term for the idea that private parties have a role in the tasks traditionally seen as the role of 'regulation' ${ }^{81}$ Governance includes 'privatized regulation through cooperative standardsetting, licensing of compliant implementations, joint ventures, and other collaborative activities by market participants. ${ }^{82}$ We have seen a growing emphasis on this idea in copyright too, with recent treaties including terms encouraging 'voluntary arrangements' particularly for online enforcement of copyright. Governance-based approaches have certain efficiencies, but they raise difficult questions about both accountability and transparency. The assumption in this chapter is that a public copyright regulator ought actively to exercise oversight over private efforts.

Given the scale of online copyright infringement, and limited public resources, I would expect that a public copyright regulator would be generally favourable towards these kinds of scheme, with two provisos. First, the copyright regulator would want to be sure that procedural

80 For detailed analysis of the scheme, see Ann-Marie Bridy, 'Graduated Response AmericanStyle: "Six Strikes" measured against Five Norms' (2012) 23 Fordham Intellectual Property, Media and Entertainment Law Journal 1.

81 Julie E Cohen, 'What Privacy is For' (2013) 126 Harvard Law Review 1904, 1928.

82 Ibid. 
fairness or due process was being observed, even in private schemes. ${ }^{83}$ This might be achieved, for example, by requiring regulator approval of schemes before they come into effect. Second, a copyright regulator concerned with ensuring diversity in creation would look for ways to ensure that voluntary deals of this kind did not lock out smaller or independent creators: ${ }^{84}$ even if that meant, perhaps, subsidising participation by smaller creators.

\section{Conclusions: What can we learn from the thought experiment?}

A number of ideas have emerged from the discussion above that are worth gathering together:

- The goal of a public copyright regulator would be, not to simply enforce copyright, nor even simply to reduce infringement, but to maximise the overall societal goals of copyright, including, but not limited to, ensuring appropriate incentives;

- Pursuit, and indeed enforcement of both these goals means that both in deciding whether to enforce copyright in a given situation, and what remedies to seek, a public copyright regulator would take into account whether members of the public can access the material, on reasonable terms, from a legitimate source. The regulator could legitimately decide not to enforce copyright in content not made available on reasonable terms;

- The copyright regulator ought to approach (many) infringers at least in the first instance on the assumption that they are lawabiding types who want to do the right thing - this implies a persuasion-based approach rather than an immediately punitive or deterrence-based approach;

- Over-deterrence and over-criminalisation are likely to breed disrespect for the law. Criminal provisions and other highly punitive mechanisms ought to be confined to serious cases;

83 See further Bridy, above n 80.

84 Cf Giblin, above n 13. 
- Enforcement measures ought to be assessed holistically, directly compared for their effectiveness in promoting the full range of copyright goals, and allocated resources according to their effectiveness.

There are numerous infringement and enforcement scenarios we could analyse in depth, to consider how a public copyright regulator would analyse the situation and apply her regulatory tools. We have not considered here how she would deal with moral rights disputes; how she would handle disputes involving arguable fair use, or how best to oversee the potentially monopolistic behaviour of collecting societies insofar as they are engaged in enforcement and may impact on the persuasive force of copyright law. There simply isn't space, in one short paper, to think through every scenario.

Nevertheless, the discussion above has certain raised some possibilities that could be considered in real world copyright reform: the possibility that criminal liability and incapacitating remedies ought to be confined in legislation to serious cases; the possibility that other remedies could be assessed and even limited by reference to the degree of access the public have to copyright material; perhaps the possibility that resources for new enforcement initiatives ought to be allocated from an existing budget according to their proven or projected effectiveness.

Something as widespread as current copyright infringement is more than misbehaviour. It is, in part, resistance: resistance to the rules of copyright; resistance to the frequent threats of existential annihilation (or at least disconnection from the internet) for copyright infringers. We need copyright enforcement, because copyright rights without enforcement are a nullity. But we need a more positive vision of what enforcement could be, and how it could operate to promote the goals of the copyright system. I hope that my thought experiment has proved it has value, in that it offers a different way of thinking through enforcement issues - in particular, shifting our attention away from the deterrence death spiral and into more positive ways of thinking about building legal compliance and a more positive vision of copyright and how we can promote the societal goals of copyright. 
This text is taken from What if we could reimagine copyright?, edited by Rebecca Giblin and Kimberlee Weatherall, published 2017 by ANU Press, The Australian National University, Canberra, Australia. 